KARL DU FRESNE is a former editor of The Dominion and a media commentator.

\section{A strong case for fair, neutral}

\section{reporting}

Flat Earth News, by Nick Davies. London: Chatto \& Windus, 2008. 408 pp. ISBN 9780701181451

A NY book about the news media that gets rave reviews from journalists as ideologically opposed as John Pilger and Peter Oborne deserves our attention. Pilger is an impassioned leftist crusader, the scourge of supposedly imperialistic Western powers and a trenchant critic of 'mainstream' journalism; Oborne is a contributor to the rightwing Spectator and an uncompromising conservative.

It is unlikely there are many issues on which these two agree, but if the blurb on the dust jacket for Nick Davies' book Flat Earth News is to be believed, Pilger described it as a 'brilliant' book, 'ruthless in its honesty' while Oborne said of it: 'This is an

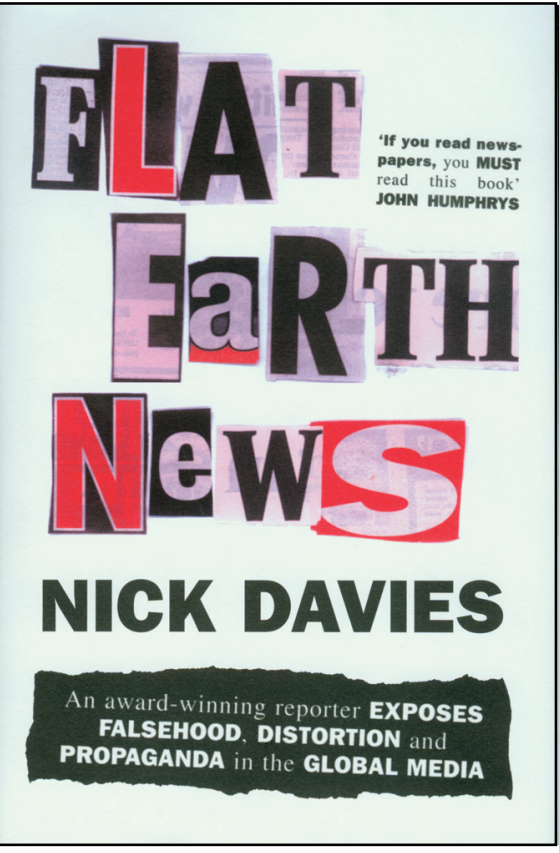

exceptionally important book which should be read, re-read and inwardly digested by all reporters, editors and proprietors.' Clearly, Davies is on to something.

Flat Earth News is a 400-page exposé of shonky practices by the British media - and not just the scurrilous London tabloids, which would surprise no one, but by some of the so-called 'quality' broadsheets as well, including Davies' own paper, The Guardian (though it must be said The Guardian emerges looking a little purer than some of its competitors).

Davies takes as his starting point the blizzard of misinformation disseminated by the media over 
Iraq's non-existent weapons of mass destruction, and the failure of journalists to dig beneath the propaganda. He says he started out trying to explain 'how we had managed to do so badly in covering what is probably the single biggest story of our era'. He goes on: 'The more I looked, the more I found falsehood, distortion and propaganda running through the outlets of an industry which is supposed to be dedicated to the very opposite, i.e. to telling the truth' (p. 2).

He develops several themes, among them:

- The increasing influence of PR firms, spin doctors and pressure groups in manipulating the news agenda, and the media's complicity in the process;

- The advent of what he calls 'churnalism', in which credulous and/ or overworked journalists unquestioningly process wrong, misleading or second-hand information;

- The steady reduction in the number of journalists reporting unglamorous but important local news such as court proceedings and council meetings (I loved Davies' line [p. 78] that judges are as likely to see a zebra in London courts as a reporter);

- The emergence of a new type of newspaper owner whose papers are run according to the 'logic of pure commerce' (p. 65) rather than by any commitment to journalism values, for which Davies largely blames (I believe unfairly) Rupert Murdoch;

- The increasing pressure, in the digital era, to turn news around fast, without adequate checking and verification;

- The willingness of the British press, including supposedly respectable titles such as the Sunday Times, to use a wide repertoire of sleazy, underhand and sometimes illegal means to get storiesincluding bribing police officers, paying private investigators for illegally obtained information and setting up elaborate traps in the hope of catching corrupt politicians, even where there is no evidence of misbehaviour.

It is an assiduously researched book, jam-packed with detail and wellwritten, as you might expect of an award-winning Guardian journalist. Davies forcefully reminds us of one of the most important journalistic values: question everything and accept nothing at face value.

But he is not entirely consistent. Davies tries hard to be fair-he is tough on Greenpeace and its alarmist stunts (pp. 190-192), and he acknow ledges a bad error of his own that was 
based on an ideological assumption (pp. 125-126) — but his own personal preoccupations and political leanings intrude from time to time. At times one senses the familiar anguished cry of the idealistic leftie who is frustrated because the media are ignoring the stories he thinks are important.

$\mathrm{He}$ is not fond of Christians, Margaret Thatcher or Israel, and it might or might not be significant that all the unreported scandals he uncovers, for which he excoriates the media, are ones that reflect unfavourably on what might loosely be called 'the establishment'.

At one point (p. 310) he describes, without criticism, a disgraceful act of deception in 1988 by Roy Greenslade, then managing editor for news at the Sunday Times. Perhaps Greenslade escaped Davies' censure because of the former's sainted status as a media commentator for The Guardian.

Davies also suffers from an occupational disorder, common among British journalists, that I call Rupertaphobia. Like many Brits, he seems never to have adjusted to the idea that an impertinent colonial upstart could take over so much of the British media. Never mind that it was largely through Rupert Murdoch that the British newspaper industry, which had long had been held hostage by greedy unions, was eventually liberated from primitive 19th century technology and disgraceful union rorts.

Ironically, Davies is fashionably dismissive of the notion of journalistic objectivity (pp. 109-114). I say 'ironically' because it seems to me that his entire book, with its justifiably scathing indictments of secret agendas, distortion and manipulation, is a powerful argument for fair, neutral reporting uncontaminated by covert interests and biases.

None of the book's failings should detract from the fact that Flat Earth News is an important, cautionary tale, and one that will shake people's faith in British journalism. But British journalism has always been about extremes of good and bad: the scurrilous tactics of the Sun and Daily Mail (for which Davies reserves special contempt) on one hand and bold, resourceful journalism uncovering corruption and abuse of power (such as the Sunday Times' exposure of the cash-for-peerages scandal) on the other.

And how much of this, if any, is applicable to New Zealand? Certainly, New Zealand journalists will nod in recognition at some of the trends Davies describes: the baleful influence of PR and spin, the pressure on newspapers to do more with fewer staff, the gradual attenuation of the 
grassroots-level journalism (such as coverage of courts and council meetings) that was once the meat and drink of the daily press. Older New Zealand journalists probably also lament, as Davies does, the passing of an older generation of newspaper proprietors who, for all their stuffy conservatism, had a strong newspaper ethos, although we shouldn't get too dewy eyed over some mythical golden era.

On the really crucial stuff relating to ethics, however, the New Zealand media have kept their noses admirably clean. Ethical corners are most likely to be cut where multiple media outlets are competing toe-to-toe, as in the case of Fleet St (metaphorical home, at least, to 14 daily titles and 10 Sundays). In New Zealand, that sort of intense competition really exists only between the two major TV networks, the trashy women's magazines and the Sunday papers. It is in those branches of the media that journalists are most likely to be ethically compromised in the chase for the exclusive story, but even there it's relatively rare. Let's hope it stays that way.

This review was originally published in the Scoop Review of Books.
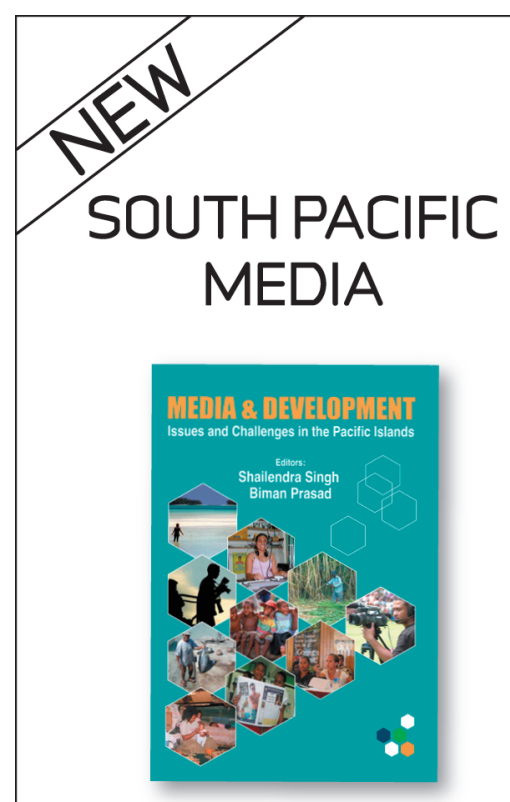

Media and Development: Issues and Challenges in the Pacific Islands

\section{Edited by Shailendra Singh and Biman C. Prasad}

This new book considers questions key development issues shaping the region's progress. Contributers include scholars, journalists and educators.

Published by the Fijian Institute of Applied Studies and the AUT Pacific Media Centre.

\section{PACIFIC MEDIA CENTRE} AUTUNIVERSITY

Order from South Pacific Books Ltd www.sthpac.netstep.co.nz sales 国southpacificbooks.co.nz Content details 国: www.pmc.aut.ac.nz/publications.html Price: NZ\$50

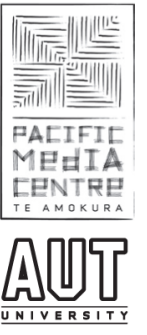

